\title{
Barriers to and facilitators of hepatitis $C$ virus screening and testing: A scoping review
}

\author{
N Shehata ${ }^{1}$, T Austin $^{1 *}, \mathrm{~S} \mathrm{Ha}^{1}, \mathrm{~K}$ Timmerman ${ }^{1}$
}

\section{Abstract}

Background: As part of the global effort to eliminate hepatitis $\mathrm{C}$ virus (HCV), it is important to understand the barriers to and facilitators of HCV screening and testing.

Objective: To examine the barriers and facilitators experienced by health care providers offering HCV screening and testing and patients seeking HCV testing.

Methods: A literature search was conducted using Embase, Medline and Scopus databases to collect studies published between January 2012 and July 2017 . We extracted the following data: author, year of publication, study design, population, setting, country, method of data collection, and knowledge and awareness outcomes.

Results: A total of 16 articles were identified. Barriers to HCV screening and testing among patients included low self-perceived risk of acquiring HCV, perceived stigma and fear of a positive result. Facilitators of HCV screening and testing, as reported by patients, included increased knowledge of transmission and manifestations of HCV infection and having HCV testing included as part of routine care with or without HIV testing. Barriers to offering HCV screening and testing included time constraints, lack of specific knowledge about HCV and discomfort in asking about risk behaviours. Facilitators of offering HCV screening and testing included testing reminders and working in locations with a higher HCV caseload.

Conclusion: Lack of knowledge and fear of stigma and discrimination remain barriers to HCV testing at the patient level and lack of time, knowledge and discomfort in asking about risk behaviours remain barriers to offering HCV testing by health care providers. This identifies potential areas for future public health action.
Affiliation

${ }^{1}$ Centre for Communicable Diseases and Infection Control, Public Health Agency of Canada, Ottawa, ON

*Correspondence: tujuanna. austin@canada.ca

Suggested citation: Shehata N, Austin T, Ha S, Timmerman K. Barriers to and facilitators of hepatitis C virus screening and testing: A scoping review. Can Commun Dis Rep 2018;44(7/8):166-72. https://doi.org/10.14745/ ccdr.v44i78a03

Keywords: barriers, facilitators, screening, testing, hepatitis C

\section{Introduction}

In 2016, the 69th World Health Assembly approved the Global Health Sector Strategy to eliminate hepatitis C virus (HCV) and hepatitis $B$ virus as a public health threat by 2030 (1). This goal has been made possible as a result of the availability of the new interferon-free direct acting antiviral (DAA) therapies, which are highly effective in stopping the progression of liver disease and eliminating the virus (2).

One of the challenges with diagnosing HCV infection is that it is often asymptomatic. Screening and testing for HCV infection is a fundamental step in identifying those who are unaware of their infection. Furthermore, the diagnosis of HCV infection can help reduce the burden of disease and limit transmission to those at increased risk of infection and those at risk of reinfection (3). The more people with HCV infection are treated, the less transmission and the fewer new cases. Thus screening and testing is critical to achieving the World Health Assembly's targets.

In 2011, it was estimated that $44 \%$ of people who were living with chronic HCV infection in Canada were unaware of their infection (4). Current Canadian HCV screening guidelines recommend screening of individuals at increased risk of infection (5). People at high risk include individuals with current or past history of injection drug use, HIV-positive gay/bisexual men who have sex with men, incarcerated populations, people experiencing homelessness, individuals exposed to previous health care procedures or personal services where there is a lack of infection prevention control, and individuals who were born, travelled, or resided in countries with high HCV prevalence (6).

The objective of this scoping review is to examine the current barriers to and facilitators of HCV screening and testing from the perspectives of both patients and health care providers. 


\section{Methods}

In this scoping review, we sought to examine the barriers to and facilitators of HCV testing among health care providers, patients and individuals other than injection drug users at risk of HCV infection. The rationale for this was that barriers to and facilitators of HCV screening and testing among people who inject drugs are well-documented (7). In addition, people who inject drugs tend to have high testing rates (5). Yet, few studies have examined the barriers to and facilitators of HCV screening and testing among other at-risk populations including where there may be a hidden burden.

We conducted a literature search for studies published between January 2012 and July 2017 to capture the most recent studies in the changing landscape of HCV screening and testing. We searched Embase, Medline and Scopus using the search terms "hepatitis C" or "HCV" and "screen" or "test" and "barriers" or "facilitators." (Search strategy available upon request)

Studies were included if they were published between January 2012 and July 2017; published in English or French; focused on populations other than people who inject drugs; and conducted in well-resourced countries. Letters to the editors, narrative reviews and commentaries were excluded. Key populations were not determined a priori but rather emerged from the results of the search.

Once the articles were identified, title and abstracts were screened for relevance. We extracted data on the study population, location of study, study design, outcomes and results.

\section{Results}

Of the 126 articles identified in the search, 16 studies focused on the barriers to and facilitators of HCV screening and testing (Figure 1).

\section{Figure 1: Search strategy flow diagram}

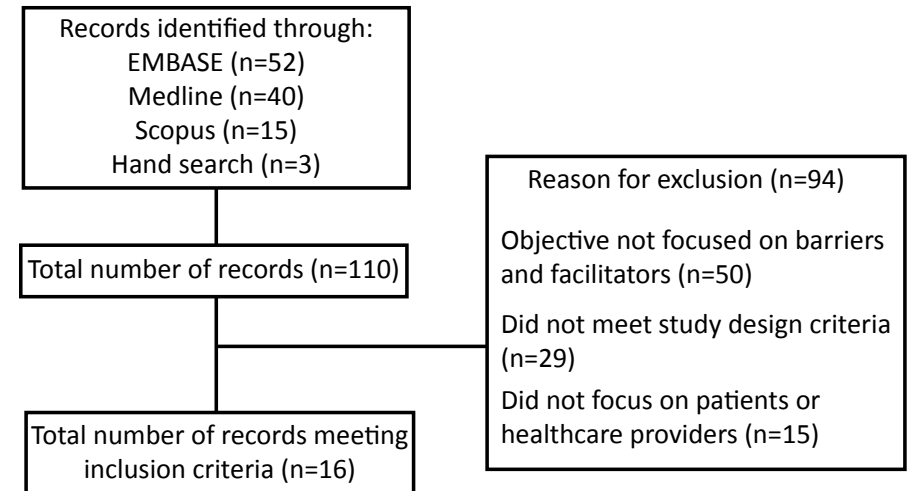

Abbreviation: $n$, number

Most of the studies examined both health care provider and patient populations. Health care providers included general practitioners, clinical representatives from hospitals, newly qualified doctors, medical students, resident physicians and nurses (8-14). Patient groups included adults born between 1945 and 1965; patients attending sexually transmitted infections (STI) clinics, outpatient clinics or primary care facilities; youth and adults working in HIV/HCV prevention; immigrant and migrant populations; and sex workers $(10,12,13,15-23)$.

Most of the studies were conducted in the United States $(n=9)$, followed by Canada $(n=2)$, United Kingdom $(n=2)$, Australia $(n=1)$, France $(n=1)$ and Scotland $(n=1)$. Study designs included observational studies, cross-sectional studies and qualitative interviews.

\section{Barriers for health care providers}

We identified three primary categories of barriers to health care providers offering $\mathrm{HCV}$ screening and testing: time constraints, lack of HCV specific knowledge and discomfort with discussing HCV. These barriers were reported across all specialities (i.e., by emergency department nurses, general practitioners, new medical residents) and settings (i.e., in emergency rooms, community health centres, primary care and STI clinics).

\section{Time constraints}

Time constraints-more specifically, limited consultation times, competing priorities and lengthy pre- and post-test counselling procedures-were commonly cited barriers to HCV screening and testing (8,10-13). As a result, health care providers-especially general practitioners-did not routinely ask patients about HCV risk factors $(8,21)$. HCV is also often accorded a low priority due to its slow progression compared with other health conditions that may need to be addressed during an appointment $(8,11,15)$.

Lengthy counselling procedures also emerged as a barrier to health care providers offering HCV testing. In a study conducted in an American teaching hospital, $75 \%$ of patients in a hospital setting were not screened because the medical resident circumvented the screening process (21).

\section{Lack of specific knowledge}

Health care providers demonstrated a general understanding of HCV risk factors but recognized the need for improving their knowledge of who to test $(8,11)$. In a study conducted in Scotland, health care providers also reported limited knowledge about counselling, to whom and where to refer diagnosed patients and protocols for testing (11). Lack of knowledge of screening guidelines was also a barrier (12).

\section{Lack of comfort}

Most health care providers understand the importance of addressing risk factors and diagnosing $\mathrm{HCV}$; however, many reported difficulties in raising the subject with their patients (9). This was especially true if the patient did not have regular contact with the provider and patient-provider rapport was limited. Providers reported that they were more comfortable offering testing after they had built a rapport with their patient and had learned about patients' history and risk factors (8).

Location of practice was an important factor that contributed to health care providers' comfort with HCV screening and testing. In regions with high prevalence of HCV infection, health care providers were more comfortable with offering testing. In contrast, health care providers who worked in regions with low $\mathrm{HCV}$ infection prevalence were less likely to encounter cases of 
$\mathrm{HCV}$ and were less likely to be comfortable with offering a test (8).

\section{Patient barriers to testing}

Common patient barriers to seeking $\mathrm{HCV}$ testing include lack of knowledge; low perceived risk of infection; fear, stigma and discrimination; and limited access to health care services.

\section{Lack of knowledge}

Lack of knowledge about HCV including risk factors, routes of transmission, manifestations and outcomes of untreated infection were frequently reported as barriers to patients seeking $\mathrm{HCV}$ testing. Knowledge gaps are evident among patients of all levels of risk. In addition, HIV/HCV stakeholders believed that health care providers' reluctance to discuss HCV contributed to youth and adults' reluctance to seek or discuss testing (18).

\section{Low perceived risk of infection}

Lack of knowledge about HCV leads to low self-perceived risk of infection, which in turn leads to under- and undiagnosed cases of HCV infection. Patients frequently reported not being at risk for $\mathrm{HCV}$ infection or not having any risk factors $(11,15,19)$. Moreover, patients who had had a previous HCV test were more likely to not seek testing again (19).

\section{Fear, stigma and discrimination}

In a Canadian qualitative study, youth and adult HIV/ HCV-prevention stakeholders reported that stigmatizing perceptions and negative attitudes about HIV/HCV persist and are a significant barrier to patients seeking testing (18). Other studies have also reported patients-particularly immigrant and migrant populations-fearing a positive HCV diagnosis and the associated stigma and discrimination as barriers to $\mathrm{HCV}$ screening $(19,20,22)$.

\section{Limited access to the health care system}

Limited interactions with the health care system, lack of a primary care provider and an unstable socioeconomic status were all identified in the literature as barriers to HCV testing reported by patients. Adults born between 1945 and 1965 have reported cost of testing, lack of health insurance, limited access to hepatology clinics and long wait times for appointments as barriers to HCV screening $(13,19)$. Language barriers and lack of culturally sensitive health services limit migrant populations' access to HCV testing $(20,22,23)$.

\section{Health care provider facilitators}

Two key facilitators to health care providers offering HCV screening and testing are awareness and knowledge of HCV risk factors and reminders through electronic medical record (EMR) flags.

\section{Awareness and knowledge of risk factors}

Awareness and knowledge of HCV risk factors can help health care providers facilitate HCV screening and testing. In a study conducted by McLeod et al. (2017) in Scotland, general practitioners reported almost always offering an $\mathrm{HCV}$ test to patients with abnormal liver function test results when they are aware of the risk factors (11).

\section{Electronic medical record flags}

A common facilitator of offering HCV screening and testing were reminders. Such reminders could decrease missed opportunities for testing. Health care providers mentioned computerized prompts built into EMRs, based on the patient's health history and risk factors, as a method of being reminded $(8,9)$. This could help ensure that patients who had not been previously offered a test or who had previously declined a test not miss other opportunities for testing. Although one study described "electronic medical record flag fatigue" (where health care providers receive too many reminders) (10), other studies noted health care providers' forgetfulness as a barrier to screening and suggest EMR flags as a solution (8).

\section{Patient facilitators}

A key facilitator of seeking HCV testing is awareness and knowledge of HCV.

\section{Awareness and knowledge}

Enhanced patient education emerged as an important facilitator of HCV testing. Education, either directly (i.e., health care providers informing patients about the risks of HCV infection) or through awareness campaigns (e.g., television advertisements, poster and public health campaigns), lets patients know the risk factors, routes of transmission and other general information on $\mathrm{HCV}$, which could make them more likely to seek testing $(8,19,20)$.

Table 1 summarizes the key barriers to and facilitators of HCV screening and testing. Details of the included studies are shown in Appendix 1.

\section{Table 1: Summary of the key barriers to and facilitators of HCV screening and testing}

\begin{tabular}{|c|c|c|}
\hline Population & Barriers & Facilitators \\
\hline $\begin{array}{l}\text { Health care } \\
\text { providers }\end{array}$ & $\begin{array}{l}\text { - Time constraints } \\
\text { - Lack of HCV-specific } \\
\text { knowledge } \\
\text { - Lack of comfort discussing } \\
\text { HCV } \\
\text { - Lack of awareness } \\
\text { and knowledge } \\
\text { of HCV screening } \\
\text { recommendations }\end{array}$ & $\begin{array}{ll}\text { - } & \text { HCV screening } \\
& \text { recommendations } \\
\text { - } & \text { Electronic medical } \\
& \text { record flags }\end{array}$ \\
\hline Patients & $\begin{array}{l}\text { - Lack of knowledge } \\
\text { - Low perceived risk of } \\
\text { infection } \\
\text { - Fear of a positive } \\
\text { - } \text { diagnosis } \\
\text { - } \text { Stigma and discrimination } \\
\text { migrant populations } \\
\text { - Lack of culturally sensitive } \\
\text { - } \text { health services } \\
\text { - Cost of testing } \\
\text { - Lack of health insurance }\end{array}$ & $\begin{array}{l}\text { - Awareness and } \\
\text { knowledge of HCV } \\
\text { - Previous HIV testing }\end{array}$ \\
\hline
\end{tabular}




\section{Discussion}

This scoping review presents a high-level snapshot of the barriers to and facilitators of health care providers offering HCV screening and testing and of patients seeking HCV testing. Barriers experienced by health care providers included time constraints, lack of specific knowledge about HCV and lack of comfort discussing HCV. Common barriers for patients were: lack of knowledge, low perceived risk of infection, fear of a positive diagnosis, stigma and discrimination, and limited access to the health care system. Facilitators for health care providers to screen were: electronic medical record flags and awareness and knowledge of HCV. Facilitators for patients to request screening were: awareness and knowledge of HCV. Given the estimated prevalence of undiagnosed cases of HCV infection, results of this scoping review are important for raising awareness of factors that facilitate and hinder HCV testing.

This review has two limitations. First, as a result of the variation in time and place of the studies, some refer to first-generation DAAs, while others refer to second generation DAAs. Although the review focused on barriers to and facilitators of HCV testing, it is important to note the treatment landscape when interpreting findings, particularly considering that some barriers (i.e., cost of treatment, fear of a positive result) may be linked to the availability of treatment.

Second, there are some limitations inherent to the methodological designs of the included studies. For example, seven of the studies were cross-sectional designs, which are only able to capture data at a specific point in time. Other limitations, such as sampling bias may also be applicable to some of the included studies.

The results from this review align with previous research and add to the literature on HCV screening and testing, particularly the barriers and facilitators. A strength of this review is the focus on populations other than injection drug users, including other at-risk populations (i.e., migrants, and sex workers), as well as the general public. Future research could include assessing the barriers to and facilitators of hepatitis $C$ testing in special populations (e.g., Indigenous communities, remote/isolated regions) where the diagnostic and treatment environments of testing are unique.

\section{Conclusion}

Understanding the barriers to and facilitators of HCV screening and testing can inform public health actions to improve risk-based screening and reduce the number of individuals unaware of their HCV infection. Informed patients and health care providers who are given the means to address stigma and discomfort around HCV could help advance the goal of HCV eradication.

\section{Authors' statement}

NS - Writing (first draft - background and methods), data curation (extraction)

TA - Data curation (verification), formal analysis, writing (final draft), review and editing
$\mathrm{SH}$ - Conceptualization, methodology, writing (final draft), data curation, validation, formal analysis, reviewing and editing, supervision, project administration, visualization KT - Conceptualization, methodology, reviewing and editing, supervision, project administration, visualization NS and TA contributed equally to this article.

\section{Conflict of interest}

None.

\section{Acknowledgements}

We would like to thank Dr. Margaret Gale-Rowe, Dr. Jun Wu and Margaret Bodie for their contributions to the revision of this manuscript and Audréanne Garand for her support in the data curation and initial analysis.

\section{Funding}

This work was supported by the Public Health Agency of Canada.

\section{References}

1. World Health Organization. Global Health Sector Strategy on Viral Hepatitis. 2016-2021: towards ending viral hepatitis. Geneva: World Health Organization; 2016. http://apps.who. int/iris/bitstream/10665/246177/1/WHO-HIV-2016.06-eng. pdf?ua=1

2. Micallef JM, Kaldor JM, Dore GJ. Spontaneous viral clearance following acute hepatitis $C$ infection: a systematic review of longitudinal studies. J Viral Hepat 2006 Jan;13(1):34-41. http://dx.doi.org/10.1111/j.1365-2893.2005.00651.x. PubMed (https://www.ncbi.nlm.nih.gov/pubmed/16364080)

3. Westbrook RH, Dusheiko G. Natural history of hepatitis C. J Hepatol 2014 Nov;61(1 Suppl):S58-68. http://dx.doi. org/10.1016/j.jhep.2014.07.012. PubMed (https://www.ncbi. nlm.nih.gov/pubmed/25443346)

4. Trubnikov M, Yan P, Archibald C. Estimated prevalence of hepatitis C virus infection in Canada, 2011. Can Commun Dis Rep 2014 Dec;40(19):429-36. PubMed (https://www.ncbi.nlm. nih.gov/pubmed/29769874)

5. Public Health Agency of Canada. Summary of key findings from I-Track Phase 3 (2010-2012). Ottawa (ON): Public Health Agency of Canada; 2014. http://www.phac-aspc.gc.ca/aidssida/publication/reports/i-track-phase-3/assets/pdf/i-trackphase-3-eng.pdf

6. Pinette GD, Cox JJ, Heathcote J, Adamowski K, Riehl G. Primary care management of chronic hepatitis $C$ : professional desk reference 2009. Ottawa (ON): Public Health Agency of Canada; 2009. Joint publication: College of Family Physicians of Canada. http://www.catie.ca/sites/default/files/PrimaryCare-Management-of-Chronic-Hepatitis-C-Professional-DeskReference.pdf

7. Barocas JA, Brennan MB, Hull SJ, Stokes S, Fangman JJ, Westergaard RP. Barriers and facilitators of hepatitis C screening among people who inject drugs: a multi-city, mixed-methods study. Harm Reduct J 2014 Jan;11(1):1. http:// dx.doi.org/10.1186/1477-7517-11-1. PubMed (https://www. ncbi.nlm.nih.gov/pubmed/24422784) 
8. Datta S, Horwood J, Hickman M, Sharp D. Case-finding for hepatitis $C$ in primary care: a mixed-methods service evaluation. Br J Gen Pract 2014 Feb;64(619):e67-74. http:// dx.doi.org/10.3399/bjgp14X677112. PubMed (https://www. ncbi.nlm.nih.gov/pubmed/24567619)

9. Duerme R, Maulana S, Schwartz J, Johnson N, Rude EJ, Laraque F. Foundation for a clinical intervention on hepatitis C: a 2015 survey of New York City hospitals' capacity to cure. Hepatology 2016;63(1):414A. https://liverlearning.aasld. org/aasld/2016/thelivermeeting/143738/fabienne.laraque. foundation.for.a.clinical.intervention.on.hepatitis.c.a.2015.html

10. Goel A, Shah B, Feuille C, Dieterich DT, Perumalswami PV. Electronic medical record flags have a limited impact on hepatitis $C$ virus birth cohort screening in the primary care setting: results of a multifaceted intervention to improve screening. Gastroenterology 2015;148(4):S123. http://dx.doi. org/10.1016/S0016-5085(15)30425-X

11. McLeod A, Cullen BL, Hutchinson SJ, Roy KM, Dillon JF, Stewart EA, Goldberg DJ. Limited impact of awareness-raising campaigns on hepatitis $C$ testing practices among general practitioners. J Viral Hepat 2017 Nov;24(11):944-54. http:// dx.doi.org/10.1111/jvh.12724. PubMed (https://www.ncbi.nlm. nih.gov/pubmed/28502088)

12. Szeto $B$, Venkat $D$, Cohen S. Identifying and fixing roadblocks to hepatitis $C$ screening in the primary care setting. Am J Gastroenterol 2014;109:S127-8.

13. Taylor BS, Hanson JT, Veerapaneni P, Villarreal R, Fiebelkorn K, Turner BJ. Hospital-based hepatitis C screening of baby boomers in a majority Hispanic South Texas cohort: successes and barriers to implementation. Public Health Rep 2016 May-Jun;131 Suppl 2:74-83. http://dx.doi. org/10.1177/00333549161310S212. PubMed (https://www. ncbi.nlm.nih.gov/pubmed/27168665)

14. White DA, Anderson ES, Pfeil SK, Graffman SE, Trivedi TK. Differences between emergency nurse perception and patient reported experience with an ED HIV and hepatitis $C$ virus screening program. J Emerg Nurs 2016 Mar;42(2):139-45. http://dx.doi.org/10.1016/j.jen.2015.09.010. PubMed (https:// www.ncbi.nlm.nih.gov/pubmed/26547573)

15. Allison WE, Chiang W, Rubin A, Oshva L, Carmody E. Knowledge about hepatitis $C$ virus infection and acceptability of testing in the 1945-1965 birth cohort (baby boomers) presenting to a large urban emergency department: a pilot study. J Emerg Med 2016 Jun;50(6):825-831.e2. http://dx.doi. org/10.1016/j.jemermed.2016.02.001. PubMed (https://www. ncbi.nlm.nih.gov/pubmed/26954104)
16. Aparicio C, Mourez T, Simoneau G, Magnier JD, Galichon B, Plaisance P, Bergmann FJ, Sellier P. [Proposal of HIV, $\mathrm{HBV}$ and HCV targeted screening: short period feasibility study in a free-access outpatient medical structure]. Presse Med 2012 Oct;41(10):e517-23. http://dx.doi.org/10.1016/j. Ipm.2012.01.039. PubMed (https://www.ncbi.nlm.nih.gov/ pubmed/22464893)

17. Feldman EB, Balise R, Schiff E, Whitehead N, Thomas E. Barriers to hepatitis $C$ screening in a minority population: a comparison of hepatitis $\mathrm{C}$ and human immunodeficiency virus screening rates at a community STD clinic in Miami, Florida. J Community Health 2017 Oct;42(5):921-5. http://dx.doi. org/10.1007/s10900-017-0335-6. PubMed (https://www.ncbi. nlm.nih.gov/pubmed/28353008)

18. Gahagan J, Condran B, Dube A, Jackson L, Lazarus L, Dykeman M, Harris G, Marshall Z, Proctor-Simms M, MacDonald J, Numer M. HIV/HCV prevention and youth in Atlantic Canada: implications for testing in Nova Scotia. Can J Infect Dis Med Microbiol 2015;26(Supplement B):101B. https:// www.cahr-acrv.ca/wp-content/uploads/2012/10/InfDis_26_SB_ MarApr2015_Final.pdf

19. Grannan S. Understanding patient perceptions and risk for hepatitis C screening. J Viral Hepat 2017 Aug;24(8):631-5. http://dx.doi.org/10.1111/jvh.12692. PubMed (https://www. ncbi.nlm.nih.gov/pubmed/28199776)

20. Guirgis M, Nusair F, Bu YM, Yan K, Zekry AT. Barriers faced by migrants in accessing healthcare for viral hepatitis infection. Intern Med J 2012 May;42(5):491-6. http://dx.doi. org/10.1111/j.1445-5994.2011.02647.x. PubMed (https://www. ncbi.nlm.nih.gov/pubmed/22151101)

21. Patil R, Ona MA, Saikali P, Papafragkakis C, Anand S. Hepatitis C screening barriers in 2016: unusual suspects. Gastroenterology 2016;150(4):S152. http://dx.doi. org/10.1016/S0016-5085(16)30610-2

22. Seedat F, Hargreaves S, Friedland JS. Engaging new migrants in infectious disease screening: a qualitative semi-structured interview study of UK migrant community health-care leads. PLoS One 2014 Oct;9(10):e108261. http://dx.doi.org/10.1371/ journal.pone.0108261. PubMed (https://www.ncbi.nlm.nih. gov/pubmed/25330079)

23. Socías ME, Shannon K, Montaner JS, Guillemi S, Dobrer S Nguyen P, Goldenberg S, Deering K. Gaps in the hepatitis C continuum of care among sex workers in Vancouver, British Columbia: implications for voluntary hepatitis $C$ virus testing, treatment and care. Can J Gastroenterol Hepatol 2015 Nov-Dec;29(8):411-6. http://dx.doi.org/10.1155/2015/381870. PubMed (https://www.ncbi.nlm.nih.gov/pubmed/26492129) 
Appendix 1: Characteristics of included studies on barriers to and facilitators of testing for hepatitis $C$ virus $(n=16)$

\begin{tabular}{|c|c|c|c|}
\hline $\begin{array}{l}\text { Author(s), year } \\
\text { of publication / } \\
\text { Country }\end{array}$ & $\begin{array}{l}\text { Study design / Setting / } \\
\text { Population ( } n)\end{array}$ & Barriers & Facilitators \\
\hline $\begin{array}{l}\text { Allison et al. (2016) (15) } \\
\text { US }\end{array}$ & $\begin{array}{l}\text { Cross-sectional study } \\
\text { Emergency department } \\
\text { Adults born between } 1945 \text { and } \\
1965(n=81)\end{array}$ & $\begin{array}{l}\text { - Low perceived risk of HCV infection } \\
\text { - Fear of needles and not wanting to have } \\
\text { additional blood tests } \\
\text { - Hepatitis C is a lower priority among patients }\end{array}$ & $\begin{array}{l}\text { - Acceptability of HCV testing and } \\
\text { novel testing methods }\end{array}$ \\
\hline $\begin{array}{l}\text { Aparicio et al. (2012) } \\
\text { (16) } \\
\text { France }\end{array}$ & $\begin{array}{l}\text { Observational study } \\
\text { Outpatient clinic } \\
\text { Adults attending outpatient } \\
\text { clinics }(n=272)\end{array}$ & $\begin{array}{l}\text { - Previous testing with a negative result was a } \\
\text { barrier to testing }\end{array}$ & $\begin{array}{l}\text { - Including information about } \\
\text { screening in the welcome } \\
\text { package for newcomers } \\
\text { (immigrants) } \\
\text { - Physicians and nurses offering } \\
\text { screening to patients presenting } \\
\text { to the hospital for any medical } \\
\text { concern }\end{array}$ \\
\hline $\begin{array}{l}\text { Datta et al. (2014) (8) } \\
\text { United Kingdom }\end{array}$ & $\begin{array}{l}\text { Mixed-methods study } \\
\text { Six national health service } \\
\text { practices in Bristol, United } \\
\text { Kingdom } \\
\text { Patients at risk of developing } \\
\text { HCV }(n=3,765) \\
\text { GPs }(n=17)\end{array}$ & $\begin{array}{l}\text { - Difficulty discussing risk factors with patients } \\
\text { - } \text { Forgetting to address HCV } \\
\text { - HCV is a lower priority due to its slow } \\
\text { progression } \\
\text { - Competing priorities (i.e., limited consultation } \\
\text { time) } \\
\text { - Difficulty building rapport with patients }\end{array}$ & $\begin{array}{l}\text { - When patients disclose risk } \\
\text { factors } \\
\text { - Awareness and knowledge of } \\
\text { HCV risk factors } \\
\text { - Working in a setting where there } \\
\text { is a high prevalence of HCV }\end{array}$ \\
\hline $\begin{array}{l}\text { Duerme et al. (2016) (9) } \\
\text { US }\end{array}$ & $\begin{array}{l}\text { Cross-sectional study } \\
\text { Clinical representatives }(n=27)^{\text {a }} \\
\text { Hospital }\end{array}$ & - Limited provider capacity & $\begin{array}{l}\text { - Hospital's electronic health } \\
\text { record system had an age-based } \\
\text { screening alert for high-risk } \\
\text { patients }\end{array}$ \\
\hline $\begin{array}{l}\text { Feldman et al. (2017) } \\
\text { (17) US }\end{array}$ & $\begin{array}{l}\text { Cross-sectional study } \\
\text { STI clinic } \\
\text { Patients attending an STI clinic } \\
(n=357)\end{array}$ & $\begin{array}{l}\text { - Patients with previous HIV screening were } \\
\text { more likely to have been screened for HCV }\end{array}$ & None reported \\
\hline $\begin{array}{l}\text { Gahagan et al. (2015) } \\
\text { (18) } \\
\text { Atlantic Canada }\end{array}$ & $\begin{array}{l}\text { Scoping review and qualitative } \\
\text { interviews } \\
\text { Nova Scotia Health Research } \\
\text { Foundation } \\
\text { Youth (ages } 15-24 \text { years) and } \\
\text { adult HIV/HCV-prevention } \\
\text { stakeholders }(n=48)\end{array}$ & None reported & $\begin{array}{l}\text { - Stigmatizing perceptions and } \\
\text { negative attitudes about HIV/ } \\
\text { HCV } \\
\text { - Lack of understanding regarding } \\
\text { the importance of targeted } \\
\text { testing among health care } \\
\text { providers contributed to youth's } \\
\text { reluctance to discuss or seek } \\
\text { testing }\end{array}$ \\
\hline $\begin{array}{l}\text { Goel et al. (2015) (10) } \\
\text { US }\end{array}$ & $\begin{array}{l}\begin{array}{l}\text { Observational study } \\
\text { (retrospective) }\end{array} \\
\text { Primary care setting } \\
\text { Primary care patients } \\
(n=37,223) \\
\text { Health care providers not } \\
\text { specified }\end{array}$ & $\begin{array}{l}\text { - Time constraints } \\
\text { - Competing priorities } \\
\text { - EMR fatigue }\end{array}$ & $\begin{array}{l}\text { - EMR flags to screen baby } \\
\text { boomers } \\
\text { - Screening by nonphysicians (i.e., } \\
\text { nurses) may be helpful }\end{array}$ \\
\hline $\begin{array}{l}\text { Grannan (2017) (19) } \\
\text { US }\end{array}$ & $\begin{array}{l}\text { Cross-sectional study } \\
\text { Federally qualified health } \\
\text { centre } \\
\text { Adult participants recruited } \\
\text { from a federally qualified health } \\
\text { centre }(n=111)\end{array}$ & $\begin{array}{l}\text { - Patients did not think they were at risk or } \\
\text { reported no risk factors } \\
\text { - Previous HCV test } \\
\text { - Cost of testing } \\
\text { - } \text { Fear of a positive result } \\
\text { - Providers did not tell patients that they } \\
\text { needed testing }\end{array}$ & $\begin{array}{l}\text { - Being in the baby boomer } \\
\text { cohort (born between } 1945 \text { and } \\
\text { 1965) prompted testing } \\
\text { - Awareness and knowledge of } \\
\text { HCV risk factors }\end{array}$ \\
\hline $\begin{array}{l}\text { Guirgis et al. (2012) (20) } \\
\text { Australia }\end{array}$ & $\begin{array}{l}\text { Cross-sectional study } \\
\text { Hospital liver clinic } \\
\text { Migrants }(n=60)\end{array}$ & $\begin{array}{l}\text { - Language barriers to accessing health care } \\
\text { - } \text { and not understanding medical terminology } \\
\text { - Cultural barriers to accessing health care } \\
\text { - Fear of discrimination/stigma } \\
\text { - Perceived health risk } \\
\text { - Privacy/confidentiality issues } \\
\text { - Financial concerns }\end{array}$ & $\begin{array}{l}\text { - Availability of a screening } \\
\text { program (i.e., maternity, } \\
\text { immigration, prison, schools, } \\
\text { blood donations) } \\
\text { - Greater awareness and } \\
\text { education } \\
\text { - More culturally sensitive health } \\
\text { services }\end{array}$ \\
\hline
\end{tabular}


Appendix 1: Characteristics of included studies on barriers to and facilitators of testing for hepatitis $C$ virus $(n=16)$ (continued)

\begin{tabular}{|c|c|c|c|}
\hline $\begin{array}{l}\text { Author(s), year } \\
\text { of publication / } \\
\text { Country }\end{array}$ & $\begin{array}{c}\text { Study design / Setting / } \\
\text { Population }(n)\end{array}$ & Barriers & Facilitators \\
\hline $\begin{array}{l}\text { McLeod et al. (2017) } \\
\text { (11) } \\
\text { Scotland }\end{array}$ & $\begin{array}{l}\text { Cross-sectional study (pre and } \\
\text { post survey) } \\
\text { Primary care setting } \\
\text { Newly qualified doctors and } \\
\text { medical students ( }=233 \text { pre } \\
\text { survey; } n=217 \text { post survey) }\end{array}$ & $\begin{array}{l}\text { - Patients not identifying themselves as being } \\
\text { - } \text { at risk } \\
\text { - HCor awareness of HCV among clients } \\
\text { - Lack of time for pre- and post-test counselling } \\
\text { - Insufficient staff with appropriate skill for } \\
\text { - counselling } \\
\text { - Poor awareness of HCV among staff } \\
\text { - Limited knowledge to whom and where to } \\
\text { - Limited knownodedge of testing protocols and } \\
\text { who to test }\end{array}$ & $\begin{array}{l}\text { - Most general practitioners would } \\
\text { always/almost always offer HCV } \\
\text { testing to patients with abnormal } \\
\text { liver function tests } \\
\text { - Awareness and knowledge of } \\
\text { HCV risk factors }\end{array}$ \\
\hline $\begin{array}{l}\text { Patil et al. (2016) (21) } \\
\text { US }\end{array}$ & $\begin{array}{l}\text { Observational study } \\
\text { (retrospective) } \\
\text { A teaching community hospital } \\
\text { Chart review of adults born } \\
\text { between } 1945 \text { and } 1965 \\
\text { ( } n=2,534) \\
\text { Number of internal medicine } \\
\text { respondents not specified }\end{array}$ & $\begin{array}{l}\text { - Internal medical residents circumvented the } \\
\text { - Increening test } \\
\text { resident admission note } \\
\text { - Patients had altered mental status and could } \\
\text { not give consent } \\
\text { - Screening test ordered but not sent to } \\
\text { laboratory }\end{array}$ & None reported \\
\hline $\begin{array}{l}\text { Seedat et al. (2014) (22) } \\
\text { United Kingdom }\end{array}$ & $\begin{array}{l}\text { Qualitative study } \\
\text { Migrant community } \\
\text { Migrant community health care } \\
\text { leads }(n=20)\end{array}$ & $\begin{array}{l}\text { - } \text { Accessibility of health care services for } \\
\text { - } \text { migrant communities } \\
\text { - Stigma and discrimination } \\
\text { - Fear of a positive result } \\
\text { - Screening services are not migrant friendly/ } \\
\text { - Lack of cultural sensitivity } \\
\text { - Lack of entitlement to free health care } \\
\text { Confidentiality issues }\end{array}$ & None reported \\
\hline $\begin{array}{l}\text { Socias et al. (2015) (23) } \\
\text { Vancouver, BC }\end{array}$ & $\begin{array}{l}\text { Observational study } \\
\text { Female sex workers }(n=705)\end{array}$ & $\begin{array}{l}\text { - Language barriers to health services } \\
\text { - Participants with higher number of clients } \\
\text { - Immigrants living in Canada }\end{array}$ & None reported \\
\hline $\begin{array}{l}\text { Szeto et al. (2014) (12) } \\
\text { US }\end{array}$ & $\begin{array}{l}\text { Observational study } \\
\text { (retrospective) } \\
\text { Primary care setting } \\
\text { Adults born between } 1945 \text { and } \\
1965 \text { ( } n=395) \\
\text { Resident physicians }(n=45)\end{array}$ & $\begin{array}{l}\text { - Lack of awareness and knowledge of } \\
\text { screening guidelines } \\
\text { - Time constraints to care for patients with } \\
\text { complex medical history }\end{array}$ & None reported \\
\hline $\begin{array}{l}\text { Taylor et al. (2016) (13) } \\
\text { US }\end{array}$ & $\begin{array}{l}\text { Descriptive study } \\
\text { Hospital } \\
\text { Adults born between } 1945 \text { and } \\
1965(n=2,327)\end{array}$ & $\begin{array}{l}\text { - Time constraints (i.e., nurses found the } \\
\text { informed consent process too onerous) } \\
\text { - Lack of health insurance among patients } \\
\text { - Limited access to hepatology clinics, long } \\
\text { waits for new appointments, difficulty } \\
\text { navigating the referral process }\end{array}$ & None reported \\
\hline $\begin{array}{l}\text { White et al. (2016) (14) } \\
\text { US }\end{array}$ & $\begin{array}{l}\text { Cross-sectional study } \\
\text { Emergency department } \\
\text { Emergency department nurses } \\
(n=65) \text { and patients }(n=491)\end{array}$ & $\begin{array}{l}\text { - Nurses frequently misperceived how patients } \\
\text { experience HCV screening, assuming patients } \\
\text { are uncomfortable with it }\end{array}$ & None reported \\
\hline
\end{tabular}

Abbreviations: BC, British Columbia; EMR, electronic medical record; GP, general practitioner; HCV, hepatitis C virus; HIV, human immunodeficiency virus; STI, sexually transmitted infection; US, United States

a $n$ refers to the number of hospitals 